\title{
PRODUCT PERFORMANCE ASSESSMENT IN 2013 CURRICULUM FOR ELEMENTARY SCHOOL STUDENTS
}

\author{
Yuyun Dwi Haryanti \\ Universitas Majalengka \\ yuyundwiharyanti18@gmail.com
}

\begin{tabular}{l} 
Article History \\
\hline accepted 09/07/2018 \\
approved 01/08/2018 \\
published 17/09/2018
\end{tabular}

Keywords

Curriculum 2013,

Performance Assessment, Product

\begin{abstract}
Assessment on the 2013 Curriculum focuses on performance assessment. Performance assessment as a broad-range assessment of student activity in which students are not only able to complete sentences, write essays but conduct research, investigations, analyze situations and data, to communicate and collaborate. Therefore, the students real performance to build performance naturally and at the same time develop thinking, reasoning, intellectual, and self-mating skills. Assessment of the product as a basis for student assessment because it requires students to apply the initial knowledge to solve problems that are realistic experienced students. Students solve various problems encountered and then expressed through the explanation he made either in the form of writing, pictures, or other products. The development of the $21^{\text {st }}$ century is characterized by increasingly fierce competition in both the business world and the world of work. Appropriate, the process of learning, especially at the elementary school equip students development entrepreneurial spirit and have life skills.
\end{abstract}

Social, Humanities, and Education Studies (SHEs): Conference Series https://jurnal.uns.ac.id/shes 


\section{PENDAHULUAN}

Penilaian dalam dunia pendidikan memiliki peranan yang sangat penting karena sebagai dasar pengembangan pembelajaran. Penilaian bergantung pada ketepatan penilaian yang dikembangkan sebagai proses pengumpulan dan pengolahan informasi untuk mengukur pencapaian hasil belajar siswa. Permendikbud 81A Tahun 2013 menyebutkan bahwa penilaian harus otentik artinya mencerminkan masalah dunia nyata, bukan dunia sekolah. Penilaian otentik tidak hanya menekankan yang diketahui siswa melainkan apa yang dapat dilakukan siswa. Penilaian performa sebagai penilaian aktivitas siswa dalam proses pembelajaran. Abidin (2016) menyebutkan bahwa penilaian performa memiliki jangkauan aktivitas luas karena siswa tidak hanya melengkapi kalimat, menulis esai, melainkan siswa melakukan penelitian dan investigasi, menganalisis situasi dan data, serta kemampuan berkomunikasi dan berkolaborasi. Penilaian performa ditentukan oleh kompleksitas kognitif dan kedalaman isi yang diujukan. Penilaian dilakukan siswa melibatkan kemampuan kognitif yang kompleks serta kedalaman konten yang sedang dipelajari dalam proses pembelajaran. Oleh karena itu, penilaian performa menuntut siswa untuk membangun performa secara original dan sekaligus mengembangkan kemampuan berpikir, bernalar, bermetakognisi, dan bergulasi diri.

Lewin and Shoemaker (dalam Abidin, 2014) menyebutkan ada beberapa karakteristik penilaian performa sebagai berikut: 1) siswa memiliki beberapa pilihan dalam memilih dan mempertajam tugas yang diberikan guru,2) tugas- tugas performa yang diberikan memerlukan elaborasi antara pengetahuan inti dan proses kunci, 3) tugas performa didesain bukan hanya kepentingan dalam kelas melainkan kepentingan di luar kelas bahkan melatih nilai-nilai dan keterampilan yang dibutuhkan di dunia kerja, 4) tugas performa diselesaikan dalam jangka waktu yang beragam, 5) tugas performa harus dapat diukur agar bersifat valid, 6) tugas performa yang diberikan memiliki sistem penilaian yang eksplisit/ jelas, konsisten, dan reliabel. Karakteristik penilaian performa tersebut sebaiknya diperhatikan oleh guru selaku praktisi lapangan sehingga guru dapat melaksanakan penilaian sebagaimanamestinya.

Penilaian performa memiliki beragam bentuk penilaian. Fitzpatrick and Morrison (Johnson, et al., 2009) menyatakan bahwa penilaian performa dalam dunia pendidikan salah satunya penilaian produk. Penilaian produk dibedakan menjadi penilaian esai dan penilaian produk yang lebih kompleks. Penilaian produk esai digunakan untuk mengukur kemampuan menulis deskripsi, analisis, ataupun rangkuman dalam satu atau lebih paragraf. Produk lain yang biasanya dinilai adalah makalah, kertas kerja laboratorium, gambar, pembuatan grafik atau diagram, dan berbagai jenis produk pembelajaran lainnya.

Penilaian produk sebagai dasar penilaian siswa dalam memecahkan permasalahan berupa produk yang dihasilkan siswa. Mislevy \& Knowles (dalam Abidin, 2014)menyebutkan bahwa penilaian ini menuntut untuk mengaplikasikan pengetahuan awal yang dimilikinya untuk memecahkan berbagai permasalahan yang bersifat realistik yang dialaminya. Instrumen yang digunakan berupa daftar cek atau skala penilaian (rating scale) yang dilengkapi rubrik.Melalui penilaian produk akan memotivasi siswa dalam menghasilkan produk-produk yang inovatif.Seperti yang kita ketahui, bahwa perkembangan zaman abad 21 ini ditandai dengan persaingan yang semakin ketat baik dalam dunia usaha maupun dunia kerja. Selayaknya, proses pembelajaran khususnya pada tingkat sekolah dasar sebagai pondasi awal dalam membiasakan siswa melakukan aktivitas yang dapat mendukung tumbuhkembangnya jiwa kewirausahaan serta memiliki kecakapan hidup. Berdasarkan permasalahan tersebut bahwa penilaian produk sebagai salah satu penilaian yang pentiing digunakan dalam proses pembelajaran dengan rumusan masalahsebagai berikut: 1) Mendeskripsikan penilaian performa pada Kurikulum 2013, 2) Mendeskripsikan ragam 
penilaian performa pada Kurikulum 2013, dan 3) implementasi penilaian performa bagi siswa kelas V SD.

\section{HASIL DAN PEMBAHASAN}

\section{Konsep Penilaian Performa}

Penilaian performa merupakan penilaian yang dapat membangun jawaban siswa secara terbuka, membuat produk secara kreatif dan produktif, serta menunjukkerjakan aktivitas tertentu dengan baik (Darling-Hammond, 2014). Hal ini berarti bahwa penilaian performa dijadikan sebagai penilaian yang memiliki jangkauan aktivitas luas yang terbentang dari penilaian yang hanya mengsyaratkan siswa agar mampu melengkapi kalimat, menulis esai, melakukan penelitian dan investigasi, menganalisis situasi dan data, hingga kemampuan berkomunikasi dan berkolaborasi. Oleh karena itu, penilaian performa menuntut siswa untuk membangun performa secara original dan sekaligus mengembangkan kemampuan berpikir, bernalar, bermetakognisi, dan bergulasi diri.

Elliot (2002) berpendapat bahwa penilaian performa sebagai penilaian yang di desain untuk memandu guru dan siswa dalam mengejar praktikterbaik proses pembelajaran. Hal ini sejalan dengan pendapat Hayes, et all. (2016) menyatakan bahwa penilaian performa sebagai penilaian yang mampu memandu siswa untuk secara kreatif dan produktif menghasilkan dan mengunjukerjakan berbagai ragam kemampuan baik sebagai proses maupun hasil belajar. Kemampuan ini dipandang sangat penting keberadaanya karena selain difungsikan selama proses pembelajaran tetapi berfungsi dalam kehidupan sehari-hari baik di lingkungan sekolah, lingkungan rumah, dan lingkungan sosial masyarakat.

Penilaian performa dalam pembelajaran harus memperhatikan beberapa komponen. Sesuai dengan pendapat Johnson, et all. (2009), bahwa penilaian performa sangat ditentukan sebagai berikut: (1) autentifikasi, (2) konteks, (3) kompleksitas kognitif, (4) kedalaman isi, (5) struktur respons yang diujikan, (6) kredibilitas, (7) biaya, (8) dan pembaharuan yang dilakukan atas penilaian yang dikembangkan.Penilaian yang baik adalah penilaian yang bersifat autentik yang sesuai dengan kehidupan sehari-hari. Penilaian performa senantiasa melibatkan konteks yang jelas dan sejalan dengan kehidupan siswa. Kualitas penilaian performa ditentukan oleh kompleksitas kognitif dan kedalaman isi yang diujukan. Penilaian dilakukan siswa melibatkan kemampuan kognitif yang kompleks serta kedalaman konten yang sedang dipelajari dalam proses pembelajaran. Semakin terbuka dan semakin produktif struktur respon yang diujikan tentu semakin baik kualitas penilaian performa yang dikembangakan. Penilaian performa semakin kredibel apabila memenuhi kevalidan dan reliabel. Penilaian performa bukanlah penilaian yang membutuhkan biaya yang tinggi tetapi dikembangkan secara ekonomis, praktis, namun tetap fungsional. Instrumen penilaian dikembangakan dan diperbaharui sesuai dengan perkembangan ilmu pengetahuan, teknologi, dan tuntutan serta perkembangan zaman.

\section{Penilaian Performa Produk}

Penilaian produk sebagai penilaian terhadap proses pembuatan dan kualitas suatu produk. Penilaian produk meliputi penilaian kemampuan peserta didik dalam membuat produk-produk teknologi dan seni, seperti makanan, pakaian, hasil karya seni, (patung, lukisan, gambar), barang-barang terbuat dari kayu, keramik, plastik dan logam. Darling- Hammond L (2014) mengatakan bahwa penilaian produk sebagai penilaian performa yang paling dasar yang menuntut siswa memecahkan beragam 
masalah melalui penjelasan yang dibuatnya baik dalam bentuk tulisan, gambar, ataupun produk lainnya. Guru dalam menilai produk siswa dapat menggunakan dua cara yaitu cara holistik dan analitis. Cara holistik, yaitu penilaian berdasarkan kesan keseluruhan dari produk, biasanya dilakukan pada tahap appraisal. Cara analitis, yaitu penilaian berdasarkan aspek-aspek produk, biasanya dilakukan terhadap semua kriteria yang terdapat pada semua tahap proses pengembangan. Kemendikbud (2014) menjelaskan mengenai petunjuk teknis pelaksanaan dan acuan dalam menentukan kualitas penilaian produk.

a. Perencanaan Penilaian Produk

Langkah yang harus dipenuhi dalam merencanakan penilaian produk sebagai berikut:

1) Menentukan kompetensi yang sesuai untuk dinilai melalui produk.

2) Penilaian produk kualitas dan kuantitas produk yang dihasilkan.

3) Menyusun indikator produk berdasarkan kompetensi/ konstruk yang akan dinilai.

4) Menentukan kriteria yang menunjukkan capaian indikator pada produk yang dihasilkan.

b. Pelaksanaan Penilaian Produk

Langkah-langkah yang harus dilakukan dalam pelaksanaan penilaian produk sebagai berikut:

1) Menyampaikan rubrik sebelum pelaksanaan penilaian kepada peserta didik.

2) Memberikan pemahaman yang sama kepada peserta didik tentang kriteria penilaian.

3) Menyampaikan tugas kepada peserta didik.

4) Memberikan pemahaman yang sama kepada peserta didik tentang tugas yang harus dikerjakan.

5) Membandingkan kinerja peserta didik dengan rubrik penilaian.

6) Memetakan kemampuan peserta didik terhadap pencapaian kompetensi minimal.

7) Mencatat hasil penilaian

8) Memberikan umpan balik terhadap produk yang disusun peserta didik.

c. Acuan Kualitas Instrumen Penilaian Produk

Tugas dan rubrik sebagai instrumen dalam tes produk. Berikut ini akan diuraikan standar tugas dan rubrik.

1) Acuan Kualitas Tugas dalam Penilaian Produk

Tugas-tugas dalam produk harus memenuhi acuan sebagai berikut:

a) Tugas mengarahkan peserta didik pencapaian indikator hasil belajar.

b) Tugas dapat dikerjakan oleh peserta didik.

c) Tugas dapat dikerjakan selama proses pembelajaran atau merupakan bagian dari pembelajaran mandiri.

d) Tugas sesuai dengan taraf perkembangan peserta didik.

e) Materi penugasan sesuai dengan cakupan kurikulum

f) Tugas bersifat adil ( tidak bias gender dan latar belakang sosial ekonomi)

g) Tugas mencantumkan rentang waktu pengerjaan tugas.

2) Acuan Kualitas Rubrik dalam Penilaian Produk

Rubrik tes produk harus memenuhi beberapa kriteria berikut ini:

a) Rubrik dapat mengukur target kemampuan yang akan diukur (valid).

b) Rubrik sesuai dengan tujuan pembelajaran.

c) Indikator menunjukkan kemampuan yang dapat diamati (observasi).

d) Indikator menunjukkan kemampuan yang dapat diukur.

e) Rubrik dapat memetakan kemampuan peserta didik.

f) Rubrik menilai aspek-aspek penting pada proyek peserta didik. 


\section{Implementasi Penilaian Produk}

Implementasi Penilaian Performa dapat dilakukan dengan cara sebagai berikut:Langkah pertama dalam mengembangkan perangkat penilaian performa adalah menentukan standar yang akan dinilai. Langkah kedua yang dilakukan adalah menentukan tugas autentik. Langkah ketiga adalahmengembangkan kriteria penilaian. Langkah ini menetapkan indikator dan subindikator atas konstruk yang akan dinilai.Upaya perumusan indikator sebaiknya melakukan pengkajian pustaka sehingga indikator yang dihasilkan valid dan reliabel. Perhatikan indikator penilaian sebagai berikut:

\section{Contoh 1:}

Perhatikan Tabel 1 berikut ini.

Tabel 1. Contoh Indikator Penilaian Keterampilan

\begin{tabular}{|c|c|c|}
\hline Kompetensi Dasar & Konstruk & Indikator \\
\hline $\begin{array}{l}\text { Menceritakan secara tertulis } \\
\text { hasil kajian mengenai } \\
\text { aktivitas manusia Indonesia } \\
\text { dalam dinamika interaksi } \\
\text { dengan lingkungan alam, } \\
\text { sosial, budaya, dan } \\
\text { ekonomi. }\end{array}$ & $\begin{array}{l}\text { Menulis teks } \\
\text { eksposisi (Produk) }\end{array}$ & $\begin{array}{l}\text { 1. Isi Teks } \\
\text { 2. Sistematika Teks } \\
\text { 3. Bahasa Teks } \\
\text { 4. Teknik Penyajian }\end{array}$ \\
\hline
\end{tabular}

Berdasarkan indikator diatas, langkah selanjutnya adalah membuat rubrik penilaian. Berikut ini contoh rubrik penilaian untuk kompetensi dasar diatas adalah sebagai berikut:

Rubrik Penilaian Produk

Konstruk: Teks Eksposisi Aktivitas Manusia

Tabel 2. Rubrik Penilaian Produk

\begin{tabular}{lll}
\hline Indikator & Skor & Deskriptor \\
\hline 1. Isi Teks & 4 & $\begin{array}{l}\text { Isi terfokus pada tema dan gagasannya tepat dan } \\
\text { lengkap. } \\
\text { Isi terfokus pada tema namun gagasannya kurang } \\
\text { tepat walaupun lengkap. } \\
\text { Isi kurang terfokus pada tema dan gagasannya } \\
\text { kurang tepat walaupun lengkap. } \\
\text { Isi kurang terfokus pada tema dan gagasannya tidak } \\
\text { tepat dan tidak lengkap. } \\
\text { Teks disusun secara sistematis walaupun kohesi } \\
\text { dan koheren. } \\
\text { Teks disusun kurang sistematis walaupun kohesi } \\
\text { dan koheren. } \\
\text { Teks disusun kurang sistematis, kurang kohesi dan } \\
\text { kurang koheren. } \\
\text { 3eks disusun tidak sistematis dan kurang atau tidak } \\
\text { kohesi dan kurang atau tidak koheren. } \\
\text { Kalimat dan pilihan kata yang digunakan baku. }\end{array}$ \\
\hline
\end{tabular}


Masih terdapat beberapa kalimat dan pilihan kata yang tidak baku.

$2 \quad$ Masih terdapat banyak kalimat dan pilihan kata yang tidak baku.

$1 \quad$ Semua kalimat dan pilihan kata yang tidak baku.

4. Teknik 4 Penulisan telah memperhatikan aspek ketuntasan Penyajian dan kekreatifan.

$3 \quad$ Penulisan telah memperhatikan aspek ketuntasan namun belum menunjukkan kekreatifan.

2 Penulisan belum memperhatikan aspek ketuntasan dan belum menunjukkan kekreatifan.

1 Penulisan belum memperhatikan aspek ketuntasan dan tidak menunjukkan kekreatifan.

Sumber: Abidin, Yunus (2016)

Keterangan:

Jumlah Skor Maksimal : 16

Nilai Akhir

: (Skor diperoleh: Skor Maskimal) x 4

Contoh Penilaian

Skor Siswa

$: 8$

Nilai Akhir

$:(8: 16) \times 4=2,5$

Tabel 3. Penafsiran

\begin{tabular}{ll}
\hline Skor & Kriteria \\
\hline $3,20-4,00(80-100)$ & Sangat Baik \\
$2,80-3,19(70-79)$ & Baik \\
$2,40-2,79(60-69)$ & Cukup \\
$<2,40$ (Kurang dari $60 \%)$ & Kurang \\
\hline
\end{tabular}

Siswa tersebut memperoleh nilai akhir adalah 2,5. Dengan demikian dapat disimpulkan bahwa siswa tersebut kompetensi produk dalam menulis teks eksposisi aktivitas manusia berkategori cukup.

\section{Contoh 2:}

Perhatikan Tabel 4 berikut ini.

Tabel 4. Contoh Indikator Penilaian Keterampilan

Tema Panas dan Perpindahannya

Subtema Suhu dan Kalor

\begin{tabular}{|c|c|c|c|}
\hline Kompetensi Dasar & Konstr & & Indikator \\
\hline $\begin{array}{l}\text { 4.2 Menyajikan hasil analisis } \\
\text { tentang interaksi manusia } \\
\text { dengan lingkungan dan } \\
\text { pengaruhnya terhadap } \\
\text { pembangunan sosial, } \\
\text { budaya, dan ekonomi } \\
\text { masyarakat Indonesia. }\end{array}$ & $\begin{array}{l}\text { Membuat } \\
\text { percobaan } \\
\text { pengamatan } \\
\text { perpindahan } \\
\text { (Produk) }\end{array}$ & $\begin{array}{r}\text { laporan } \\
\text { hasil } \\
\text { tentang } \\
\text { kalor }\end{array}$ & $\begin{array}{l}\text { 1. Ketepatan Informasi yang } \\
\text { disajikan } \\
\text { 2. Kelengkapan Informasi } \\
\text { yang disajikan } \\
\text { 3. Kesimpulan }\end{array}$ \\
\hline
\end{tabular}


Berdasarkan indikator diatas, langkah selanjutnya adalah membuat rubrik penilaian. Berikut ini contoh rubrik penilaian untuk kompetensi dasar diatas adalah sebagai berikut:

Rubrik Penilaian Produk

Konstruk: Laporan percobaan hasil pengamatan

Tabel 5. Rubrik Penilaian Produk

\begin{tabular}{|c|c|c|}
\hline Indikator & Skor & Deskriptor \\
\hline \multirow{4}{*}{$\begin{array}{l}\text { 1. Ketepatan } \\
\text { Informasi yang } \\
\text { disajikan }\end{array}$} & 4 & $\begin{array}{l}\text { Siswa mendeskripsikan perubahan ukuran es batu } \\
\text { pada ketiga wadah dengan jelas dan tepat. }\end{array}$ \\
\hline & 3 & $\begin{array}{l}\text { Siswa mendeskripsikan perubahan ukuran es batu } \\
\text { pada ketiga wadah cukup jelas tetapi tepat. }\end{array}$ \\
\hline & 2 & $\begin{array}{l}\text { Siswa mendeskripsikan perubahan ukuran es batu } \\
\text { pada ketiga wadah kurang jelas dan kurang tepat. }\end{array}$ \\
\hline & 1 & $\begin{array}{l}\text { Siswa mendeskripsikan perubahan ukuran es batu } \\
\text { pada ketiga wadah tidak jelas dan tidak tepat. }\end{array}$ \\
\hline \multirow{4}{*}{$\begin{array}{l}\text { 2. Kelengkapan } \\
\text { Informasi yang } \\
\text { disajikan }\end{array}$} & 4 & $\begin{array}{l}\text { Siswa menjelaskan disertai alasan sesuai hasil } \\
\text { pengamatan dengan lengkap dan tepat. }\end{array}$ \\
\hline & 3 & $\begin{array}{l}\text { Siswa menjelaskan disertai alasan sesuai hasil } \\
\text { pengamatan dengan cukup lengkap dan tepat. }\end{array}$ \\
\hline & 2 & $\begin{array}{l}\text { Siswa menjelaskan disertai alasan sesuai hasil } \\
\text { pengamatan dengan kurang lengkap dan kurang } \\
\text { tepat }\end{array}$ \\
\hline & 1 & $\begin{array}{l}\text { Siswa menjelaskan disertai alasan sesuai hasil } \\
\text { pengamatan dengan tidak lengkap dan tidak tepat. }\end{array}$ \\
\hline \multirow[t]{4}{*}{ 3. Kesimpulan } & 4 & $\begin{array}{l}\text { Siswa menyimpulkan sesuai dengan hasil } \\
\text { percobaan. }\end{array}$ \\
\hline & 3 & $\begin{array}{l}\text { Siswa menyimpulkan cukup sesuai dengan hasil } \\
\text { percobaan. }\end{array}$ \\
\hline & 2 & $\begin{array}{l}\text { Siswa menyimpulkan kurang sesuai dengan hasil } \\
\text { percobaan. }\end{array}$ \\
\hline & 1 & $\begin{array}{l}\text { Siswa menyimpulkan tidak sesuai dengan hasil } \\
\text { percobaan. }\end{array}$ \\
\hline
\end{tabular}

Sumber: Buku Guru Kelas V Tema 6 Edisi Revisi 2017

Keterangan:

Jumlah Skor Maksimal : 12

Nilai Akhir

Contoh Penilaian

Skor Siswa

Nilai Akhir
: (Skor diperoleh: Skor Maskimal) x 4

$: 9$

$:(9: 12) \times 4=3$

Tabel 3. Penafsiran

\begin{tabular}{ll}
\hline Skor & Kriteria \\
\hline $3,20-4,00(80-100)$ & Sangat Baik \\
$2,80-3,19(70-79)$ & Baik \\
$2,40-2,79(60-69)$ & Cukup \\
$<2,40$ (Kurang dari $60 \%)$ & Kurang \\
\hline
\end{tabular}


Siswa tersebut memperoleh nilai akhir adalah 3. Dengan demikian dapat disimpulkan bahwa siswa tersebut kompetensi produk dalam menulis laporan berkategori baik.

\section{SIMPULAN}

Penilaian performa merupakan penilaian yang penting dikembangkan oleh guru. Penilaian performa sebagai penilaian yang memiliki jangkauan luas karena menilai semua kemampuan siswa baik dalam berpikir, bernalar, bermetakognisi serta bergulasi diri siswa. Penilaian performa memiliki berbagai ragam salah satunya penilaian produk. Penilaian produk adalah penilaian hasil pemecahan masalah siswa yang dituangkan dalam penjelasan melalui produk pengetahuan dan seni seperti: gambar, tulisan, atau produk yang lainnya. Sekolah Dasar sebagai pondasi awal dalam mengembangkan kemampuan siswa untuk menghasilkan produk-produk realistik sesuai dengan kehidupan sehari-hari siswa. Penilaian performa produk dapat diimplementasikan dalam proses pembelajaran di kelas V SD sebagai contoh Kompetensi Dasar "Menceritakan secara tertulis hasil kajian mengenai aktivitas manusia Indonesia dalam dinamika interaksi dengan lingkungan alam, sosial, budaya, dan ekonomi" dan "Menyajikan hasil analisis tentang interaksi manusia dengan lingkungan dan pengaruhnya terhadap pembangunan sosial, budaya, dan ekonomi masyarakat Indonesia"adapun langkah-langkah yang dapat ditempuh guru adalah sebagai berikut: 1) menentukan standar yang akan dinilai; 2) menentukan tugas autentik; dan 3) mengembangkan kriteria penilaian, langkah ini menetapkan indikator dan subindikator atas konstruk yang akan dinilai. Melalui langkah-langkah pengembangan penilaian performa tersebut maka guru dapat dengan mudah melakukan penilaian sesuai dengan standar penilaian yang telah ditetapkan pada kurikulum yang berlaku yaitu kurikulum 2013.

\section{DAFTAR PUSTAKA}

Abidin, Yunus. (2016). Revitalisasi Penilaian Pembelajaran: dalam Konteks Pendidikan Multiliterasi Abad Ke-21. Bandung: Refika Aditama.

Buku Tematik Kurikulum 2013 Edisi Revisi 2017. Buku Guru SD/MI Kelas V: Tema 6 Panas dan Perubahannya. Jakarta: Kementerian Pendidikan dan Kebudayaan.

Darling- Hammond, L. (eds.). (2014). Next Generation Assessment: Moving Beyond the Bubble Test to Support 21st Century Learning. San Fransisco: JosseyBass.

Elliot, B. (2002). Measuring Perfomance: The Early Childhood Education in Practice: For Those Who Educate and Care for Young Children. New York: Delmar, a division of Thomson Learning.

Hayes, d. et al. (2016). Teachers and Schooling Making a Difference: Productive Pedagogies, Assessment and Performance. Crows Nest, Australia: Allen \& Unwin.

Johnson, R.L. et.al. (2009). Assesing Perfomance: Designing, Scoring, and Validating Perfomance Task. New York: Guilford.

Kemendikbud. (2014). Pedoman Penilaian Kurikulum 2013. Jakarta: Kemendikbud.

Kemendikbud. 2013. Lampiran Permendikbud Nomor 81A Tahun 2013 Tentang Implementasi Kurikulum Pedoman Umum Pembelajaran. Jakarta: Kementerian Pendidikan dan Kebudayaan RI. 